\title{
Analysis of gender differences in the perception of properties: An application for differential semantics
}

\author{
Carmen Llinares; Alvaro Page \\ Universidad Politécnica de Valencia (SPAIN) \\ cllinare@omp.upv.es; alvaro.page@ibv.upv.es
}

Received December 2008

Accepted May 2009

\begin{abstract}
This paper presents the application of differential semantics to identify the semantic space (structure) used by men and women to describe their perception of properties on sale. 112 men and 43 women evaluated 112 images of flats on sale at the time of the study in the city of Valencia (Spain) using 60 adjectives. The set of attributes or variables which capture the user's perception of a property in his own words (semantic axes) was identified using factor analysis of principal components. The semantic space of a property was described by 15 independent axes which explained 64\% of the variability for males and 17 axes which explained $72.3 \%$ of the variance for females. The connection between the subject's emotional response, expressed through the set of axes (15 for males and 17 for females) and the global evaluation in terms of the purchase decision was established. The results demonstrated significant differences in the variables used by both genders to express their perception of a property on sale and the weight of these variables on the purchase decision.
\end{abstract}

Keywords: gender differences, semantic differential, building design

\section{Introduction}

There are many studies which attempt to demonstrate how aesthetic evaluations of buildings are formulated or can be predicted. These predictions are of great 
interest to architects as they can be used to establish relations between users' perceptions and each design element introduced.

Some of these studies have shown that certain sociodemographic or personality variables can affect these aesthetic evaluations. Thus for example, the studies of Wethman (1968), Royse (1969) and Michelson (1976) confirm that people of different education, income and social class view certain aspects of housing differently. Nasar (1989), also observed sociodemographic differences in the preferences of 6 styles of houses based on education, occupation, age or gender. In building interiors Gifford (1980) observed significant differences in response depending on age, gender, educational level and mood.

From among this set of variables, training in architecture has been the most analysed. In general, studies demonstrate that architects and non-architects perceive buildings differently. Differences have thus been found in the categories both groups use to interpret buildings (Groat, 1982); in the way they conceptualise them (Devlin, 1990); in the emotional responses both groups assign to a building's design elements (Gifford et al., 2000) and even differences in their preferred architectural styles (Devlin \& Nasar, 1989; Gans, 1978; Nasar, 1989).

Personality factors, such as someone's sensation-seeking level, can also affect environmental preferences. For architecture, high sensation seekers would prefer higher levels of stimulus variation (for example, "high" style houses) while others would prefer more typical designs (for example, "popular" style houses) (Berlyne, 1971; Stamps \& Nasar, 1997). Zuckerman (1994) summarizes over 400 experiments on this personality factor.

Another variable which could affect the process of environmental perception is everyday experience (Purcell \& Nasar, 1992). Our experience of the environment consists of repeated encounters of different examples. Through these repeated encounters the individual experiences a process of unconscious learning (Lewicki et al., 1988) which is used to build a mental representation of preferred standards. Some research has found that observer preferences for buildings depend on the level of discrepancy between the type of building to be evaluated and the observer's knowledge structure (Purcell, 1986, 1987; Purcell \& Nasar, 1992). This approach could explain the differences in perception found between observers from different geographical areas. Consequently, groups living in a given geographical 
area are exposed to the same types of examples and therefore share similar patterns or standards of preference.

Furthermore, there are other demographic factors which can influence the process such as gender, age or political affiliation. Thus for example, Stamps (1991a,b) found that political affiliation (liberal, moderate, conservative) was related to preferences for high rise buildings and for houses. Differences have also been observed between men and women's environmental cognition (Evans, 1980; Moore, 1979), although no in-depth analysis of the evaluation structure for both genders has been found in the literature. Thus, with regard to the perception of architectural styles, Nasar (1989) found that females in the city of Columbus judged a "farm" style to be more desirable than males did, and that females in the cities of Columbus and Los Angeles judged "farm" style as friendlier than males did. Stamps and Nasar (1997) obtained a 0.94 correlation between both groups when evaluating "high" and "popular" styles. Imamoglu (2000) studied the role of complexity in preference with 16 house facade drawings. The study reports that females perceived the houses as more complex than males. In a more recent study, Akalin et al. (2009) analysed the perception of 100 undergraduate students in Architecture and Engineering Departments. The individuals had to assess 15 photographs of house facades considering the roles of complexity, preference and impressiveness. The results showed significant differences in perceptions between gender groups. Other gender differences have been studied, such as, distance perception and the effects of the hidden buildings (Nasar et al., 1985).

Although the gender variable has generally been taken into account when segmenting the study population, no study has been found in the literature which deeply analyses the structure of preferences in both collectives.

Our question then is how are preferences formulated? The theory proposed by Brunswik in 1956 suggested that the relational process between the stimulus and the opinion or judgment emitted by the subject was an indirect one. Applied to the sphere of building design, this approach assumes that subjects respond to the particular characteristics of the building, integrate these reactions into emotional impressions and transfer those emotional impressions to an aesthetic evaluation of the building as a whole. 
In this indirect assessment process it is important to be able to determine the set of emotional reactions or words that attempt to express the impressions arising when interacting with products. The evaluation of a product is conditioned not only by stimuli but also by the concept or word set used by a given group of users. In other words, to evaluate a situation appropriately, the evaluation variables must be adapted to the users' mental set. This conceptual structure must be designed before any relation can be established between each perceived attribute and the global evaluation of the product.

Differential semantics is a technique developed in the 1950 s by Osgood et al. (1957) to analyse semantic structures and the affective meaning of things. It is a standard procedure that assumes an underlying structure in the semantic evaluation of products which it analyses using factor analysis (Osgood \& Suci, 1955). The technique analyses the correlation matrixes for the scores for terms over a set of products. If it can be demonstrated that a limited number of dimensions or factors is sufficient to differentiate between the meanings of the whole set of concepts, then these dimensions define a semantic basis for expressing any product. This semantic basis is known as semantic space and each concept is a semantic axis.

This paper uses differential semantics to analyse men and women's emotional response to real estate promotion. Specifically, the study aims to: (a) quantify the difference between the opinions in both groups on choice of a property, (b) select, for each gender, relevant words with as few words as possible to describe the semantic space for properties, (c) order, for each gender, the set of emotional attributes in relation to their influence on the choice of a property, (d) describe for both collectives the perceived images of a property in relation to that the market as a whole.

\section{Material and methods}

The methodological development focused on a field study which collected the evaluations of two groups of interviewees (men and women) for each stimulus presented. The products for evaluation were newly built, medium-high priced urban flats. 


\subsection{Subjects}

The sample comprised 155 subjects ( 112 males and 43 females), $72 \%$ of whom were between 30 and 49 years old. Staff from the Universidad Politécnica in Valencia were chosen (professors, research staff and administration and services staff). The selection technique was simple random sampling. Departments related to Architecture or Town Planning were excluded to avoid the participation of specialists whose perceptions could be very different from those of "non-expert" clients. Many studies demonstrate that architects and non-architects have totally different perceptions (Devlin, 1990; Devlin \& Nasar, 1989; Duffy et al., 1986; Friedman et al., 1985; Gans, 1978; Nasar, 1989; Nasar \& Purcell, 1990). Each subject replied to 3 questionnaires to give a total of 465 replies.

\subsection{Questionnaire}

The questionnaire contained 60 adjectives to describe the emotional response of users and professionals in the sector of the city property market. Only words and expressions in Spanish were collected. This Universe was obtained through a word search (142 adjectives) which, after applying the criteria of Jindo et al. (1995), was reduced to 60 . In addition to this list, there was a variable which reflected the global evaluation or purchase decision from the expression "Globally, I think it is a good house. Assuming it suited my financial possibilities, I would consider it to be a good purchase opportunity". A 5-point Likert scale was used to evaluate each image ranging from: totally disagree, disagree, neutral, agree, and totally agree.

\subsection{Stimuli}

The set of stimuli used to develop the field study consisted of a total of 112 images of flats. Each stimulus included all the information contained in advertising brochures (exterior view of the development, floor plan of the flat, surface areas, floor level, aspect and summary of the building specifications). No references were included on the specific location of the building in the city as the interviewees were asked to evaluate the property independently of its location. Figure 1 shows an example of the stimuli used. 

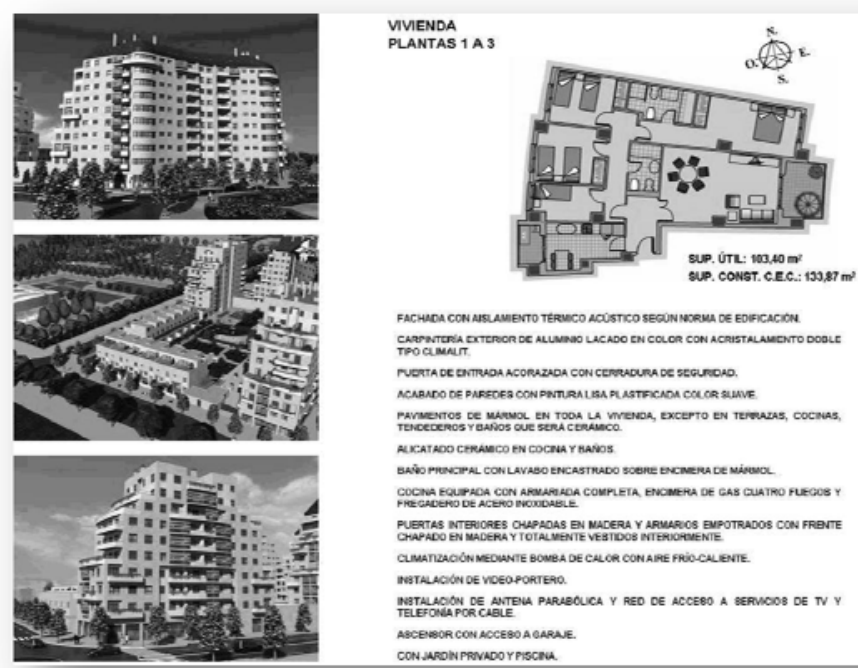

Figure 1. "Example of the stimuli used in the field study". Source: authors

\subsection{Development of the field study}

The interviewees were told that the object of the study was to collect their first impressions and therefore after observing the image, they were to complete the questionnaires quite quickly. It was considered that an interviewee could reply to a maximum of 3 questionnaires before losing interest.

\subsection{Data processing}

The following statistical procedure was applied to the database of answers (Table $1)$.

\section{PHASE}

TECHNIQUE

EXPECTED RESULT

1. Verification of the existence of differences in perception between genders

Discriminant analysis

2. Extraction of semantic axes for Principal components each gender

3. Ordering, for each gender, of semantic axes in relation to global evaluation

\section{Comparative analysis:} application to one particular flat on sale

$$
\text { factor analysis }
$$
coefficients
Quantification of the difference in perception between men and women

Reduction of the information contained in 60 adjectives to a lower number of independent factors or semantic axes

Ordering of semantic axes in relation to their significance on the global evaluation

Spearman's correlation

Evaluation of the product by both genders

Table 1. "Data treatment phases, techniques and expected results". Source: authors 
1 Verification of differences in perception. In a first phase, an exploratory analysis was carried out to determine whether there were significant differences between men and women's opinions of the 60 chosen adjectives. In a second phase, and to evaluate the differences in perception of the set of variables a discriminant analysis was carried out using gender as a grouping variable and the scores for the different adjectives as independent variables. It was thereby possible to verify the hypothesis that men and women have a sufficiently different perception structure to be able to classify a person by their responses. The indicators used to evaluate the efficiency of the discriminant function were: the percentage of correct answers classifying the subjects in the sample into the two groups determined by the dependent variable, the eigenvalue of the discriminant function, the canonical correlation and the Wilks' Lambda value.

2 Identifying semantic axes for each gender. Semantic axes are uncorrelated variables which characterise the perception of the product. Each axis includes a combination of adjectives of the original set that present significant correlations in the customers' responses. They therefore group adjectives that usually have similar evaluations and which are supposed to represent common concepts implicity used by men and women to assess properties on sale. Factor analysis was used to identify and extract the semantic axis (Basilevsky, 1994; Flury, 1988). We selected only principal components with eigenvalues greater than one, and a further Varimax rotation was made to obtain the semantic axes factors.

3 Ranking semantic axes for each gender. The attributes associated to the semantic axes represent common concepts which explain the perceived differences between housing from the customer point of view. Nevertheless, the influence of each axis on the global evaluation may be very different. This relation can be quantified by means of a statistical relationship, for example a correlation coefficient. We have used the nonparametric Spearman correlation coefficient between the factor scores and the overall opinion to measure this influence, and the axes were ranked according to this criterion.

4 Comparative analysis: semantic profiles for each gender. The semantic profile of a specific property on sale is a diagram that represents the scores obtained in each semantic axis. Since factor analysis provides scores that are centered in relation to the average of the sample analysed, the semantic profile allows the 
relative position of a particular product to be visualised in relation to the mean of the market. Obtaining the semantic profile of a flat on sale for each gender permits the visualisation of the degree of similarity or discrepancy in the preference structures of both collectives. To illustrate the use of the semantic profiles we have analysed a particular flat on sale which was not included in the above statistical analysis. The profiles were built by collecting the mean scores for the 60 adjectives in each flat which were then normalised and transformed into semantic axis scores using the transformation matrixes for the components obtained in the previous analysis.

Statistical analyses were done using statistical package SPSS 12.0.

\section{Results}

\subsection{Verification of differences in perception}

The prior exploratory analysis permitted the identification of significant differences between men and women's opinions of the following adjectives: liveable in, elegant, full of character, original, oppressive, good architectural design, delightful, safe, craftsmanship finishes, peaceful, private atmosphere, independent and community atmosphere. In a second phase and given that the grouping variable contained two categories (men-women), discriminant analysis determined a single discriminant function. The discriminating power of this function was moderate, with a canonical variation of 0.459 and an eigenvalue of 0.267 . The separation given by the discriminant function was significant, with a Wilks' Lambda value of 0.789 (see Table 2).

\begin{tabular}{|l|l|}
\hline EIGENVALUE & 0.267 \\
\hline CANONICAL CORRELATION & 0.459 \\
\hline WILKS' LAMBDA & 0.789 \\
\hline SIGNI IICATION LEVEL & 0.003 \\
\hline
\end{tabular}

Table 2. "Eigenvalue, canonical correlation, Wilks Lambda and signification level of the discriminant function". Source: authors

Furthermore, the percentage of correctly classified subjects from the sample and the validation results (leave-one-out cross-validation method) was $68.93 \%$ for women and $74.4 \%$ for men (see Table 3 ). 


\begin{tabular}{|c|c|c|c|}
\cline { 3 - 4 } \multicolumn{2}{c|}{} & \multicolumn{2}{c|}{ PREDICTED GROUP MEMBERSHIP } \\
\cline { 3 - 4 } \multicolumn{2}{c|}{} & WOMEN & MEN \\
\hline \multirow{2}{*}{ ORIGINAL } & WOMEN & $84(68.9 \%)$ & $38(31.1 \%)$ \\
\cline { 2 - 4 } & MEN & $83(25.6 \%)$ & $241(74.4 \%)$ \\
\hline
\end{tabular}

Table 3. "Classification of the subjects by discriminant analysis". Source: authors

In conclusion then, the results of the discriminant analysis demonstrated significant differences between men and women's perceptions of the set of adjectives analysed.

\subsection{I dentifying semantic axes}

Men

Principal components factor analysis was used to reduce the original 60 variables to 15 factors or independent semantic axes which explained $64.02 \%$ of the variance in the original variables. These factors are:

- 1st axis: this represents the dimension Originality, Innovative and Luxury with the adjectives "original", "innovative", "design", "full of character", "luxury", "fashionable", "delightful" and "not simple". It explains $8.49 \%$ of the variance.

- 2nd axis: with the variables "liveable in", "pleasant", "practical", "unoppressive", "plenty of cupboards and auxiliary areas", "comfortable", "cosy", "with good bathrooms" and "peaceful". It represents the dimension Liveable in, Pleasant and Practical and explains $6.07 \%$ of the sample variance.

- 3rd axis: this represents the dimension Good Layout and comprises the adjectives "neat layout", "well laid out", "simple layout", "open plan but with well differentiated areas". It explains $5.95 \%$ of the variance.

- 4th axis: this represents the dimension Refined, Elegant and Stylish with the positive adjectives "refined", "stylish", "elegant", "good architectural design", "good bathrooms" and the negative "impersonal". It explains $5.11 \%$ of the variance. 
- 5th axis: with the adjectives "safe", "guaranteed maintenance", "with quality materials and finishes", "quality" and "well-equipped" it represents the axis of Quality, Fittings and Security in the flat and explains $4.90 \%$ of the sample variability.

- 6th axis: with the variables "outward-facing", "light" and the negative "inward-facing" it represents the dimension Light and Outward Facing. It explains $4.25 \%$ of the variance.

- 7th axis: this contains the adjectives "family home", "for growing families", "spacious", "tailor made" and represents the axis Spacious, Family Home. It explains $4.06 \%$ of the sample variance.

- 8th axis: this represents the Country Style and Natural Character and covers the adjectives: "country style", "natural atmosphere", "craftsmanship finishes" and the negative "urban character". It explains $3.80 \%$ of the variance.

- 9th axis: this represents the dimension Lifelong with the adjectives "timeless, does not go out of fashion", "for all tastes", "tailor made". It explains $3.73 \%$ of the variance.

- 10th axis: with the adjectives "young" and "carefree and informal", it represents the dimension Young and Informal and explains 3.69\% of the sample variance.

- 11th axis: this contains the variables "layout with many possibilities" and "flexible layout" and represents the axis Flexible Layout and With Many Possibilities. It explains $3.19 \%$ of the variance.

- 12th axis: with the expressions "magnificent kitchen", "craftsmanship finishes", "ecological", it represents the dimension of Magnificent Kitchen. It explains $2.90 \%$ of the variance.

- 13th axis: this contains the adjectives "community atmosphere", "with good amenities" and with negative connotations "peaceful". It represents the dimension of Community Atmosphere and With Good Amenities and explains $2.89 \%$ of the variance. 


\begin{tabular}{|c|c|c|c|}
\hline $\begin{array}{c}\text { Factor } \\
\text { Axes }\end{array}$ & Meaning of Factors & Representative Terms & $\begin{array}{l}\text { Contribu- } \\
\text { tion ratio }\end{array}$ \\
\hline $\begin{array}{l}1 \text { st } \\
\text { axis }\end{array}$ & $\begin{array}{l}\text { ORIGINALITY, } \\
\text { INNOVATIVE AND } \\
\text { LUXURY } \\
\text { (Originalidad, I nnovación } \\
\text { y Lujo) }\end{array}$ & $\begin{array}{l}\text { Original }(0.792) \text {, Innovative }(0.750) \text {, Designer }(0.743) \text {, } \\
\text { Full of character }(0.735) \text {, Luxury }(0.521) \text {, Fashionable } \\
(0.466) \text {, Delightful }(0.450) \text {, Simple }(-0.403)\end{array}$ & $8.494 \%$ \\
\hline $\begin{array}{l}\text { 2nd } \\
\text { axis }\end{array}$ & $\begin{array}{l}\text { LIVEABLE IN, PLEASANT } \\
\text { AND PRACTICAL } \\
\text { (Habitable, Cómoda y } \\
\text { Práctica) }\end{array}$ & $\begin{array}{l}\text { Liveable in }(0.644) \text {, Pleasant }(0.613) \text {, Practical }(0.545) \text {, } \\
\text { Oppressive }(-0.530) \text {, Plenty of cupboards and } \\
\text { auxiliary areas }(0.490) \text {, Comfortable }(0.480) \text {, Cosy } \\
(0.467) \text {, Good bathrooms }(0.465) \text {, Peaceful }(0.464) \text {, }\end{array}$ & $6.067 \%$ \\
\hline $\begin{array}{l}3 \text { rd } \\
\text { axis }\end{array}$ & $\begin{array}{l}\text { GOOD LAYOUT } \\
\text { (Buena Distribución) }\end{array}$ & $\begin{array}{l}\text { Neat layout }(0.832) \text {, Well laid out }(0.687) \text {, Simple } \\
\text { layout }(0.686), \text { Open plan but with well differentiated } \\
\text { areas }(0.679)\end{array}$ & $5.948 \%$ \\
\hline $\begin{array}{l}\text { 4th } \\
\text { axis }\end{array}$ & $\begin{array}{l}\text { REFINED, ELEGANT AND } \\
\text { STYLISH } \\
\text { (Refinada, Elegante y } \\
\text { Bonita) }\end{array}$ & $\begin{array}{l}\text { Refined }(0.640) \text {, Stylish }(0.534) \text {, Elegant }(0.516) \text {, Good } \\
\text { architectural design }(0.495) \text {, I mpersonal }(-0.423) \text {, } \\
\text { Good bathrooms }(0.411)\end{array}$ & $5.113 \%$ \\
\hline $\begin{array}{l}5 \text { th } \\
\text { axis }\end{array}$ & $\begin{array}{l}\text { QUALITY, FITTINGS AND } \\
\text { SECURITY } \\
\text { (Calidad, Equipamiento y } \\
\text { Seguridad) } \\
\end{array}$ & $\begin{array}{l}\text { Safe }(0.711) \text {, Guaranteed maintenance }(0.699) \\
\text { Quality materials and finishes }(0.681) \text {, Quality }(0.609), \\
\text { Well-equipped }(0.436)\end{array}$ & $4.898 \%$ \\
\hline $\begin{array}{l}6 \text { th } \\
\text { axis }\end{array}$ & $\begin{array}{l}\text { LIGHT AND OUTWARD- } \\
\text { FACING } \\
\text { (Luminosa y Exterior) }\end{array}$ & $\begin{array}{l}\text { Inward-facing }(-0.849), \text { Outward-facing, open views } \\
(0.839) \text {, Light }(0.738)\end{array}$ & $4.245 \%$ \\
\hline $\begin{array}{l}\text { 7th } \\
\text { axis } \\
\end{array}$ & $\begin{array}{l}\text { SPACIOUS, FAMI LY HOME } \\
\text { (Amplia y Familiar) } \\
\end{array}$ & $\begin{array}{l}\text { Family home }(0.719), \text { For growing families }(0.629), \\
\text { Spacious }(0.550) \text {, Tailor made }(0.438)\end{array}$ & $4.058 \%$ \\
\hline $\begin{array}{l}\text { 8th } \\
\text { axis }\end{array}$ & $\begin{array}{l}\text { COUNTRY STYLE AND } \\
\text { NATURAL CHARACTER } \\
\text { (Campestre y Natural) }\end{array}$ & $\begin{array}{l}\text { Country style }(0.778) \text {, Urban }(-0.778) \text {, Natural } \\
\text { atmosphere }(0.452) \text {, Craftsmanship finishes }(0.363)\end{array}$ & $3.791 \%$ \\
\hline $\begin{array}{l}\text { 9th } \\
\text { axis }\end{array}$ & $\begin{array}{l}\text { LIFELONG } \\
\text { (Para Toda la Vida) } \\
\end{array}$ & $\begin{array}{l}\text { Timeless, doesn't go out of fashion (0.689), For all } \\
\text { tastes }(0.632) \text {, Tailor made }(0.473)\end{array}$ & $3.726 \%$ \\
\hline $\begin{array}{l}\text { 10th } \\
\text { axis }\end{array}$ & \begin{tabular}{|l|} 
YOUNG AND INFORMAL \\
(Juvenil e Informal)
\end{tabular} & Young (0.813), Carefree and informal (0.666) & $3.688 \%$ \\
\hline $\begin{array}{l}\text { 11th } \\
\text { axis }\end{array}$ & $\begin{array}{l}\text { FLEXIBLE LAYOUT AND } \\
\text { WITH MANY } \\
\text { POSSIBILITIES } \\
\text { (Distribución Flexible y } \\
\text { con Muchas Posibilidades) } \\
\end{array}$ & $\begin{array}{l}\text { Layout with many possibilities }(0.783) \text {, Flexible layout } \\
(0.767)\end{array}$ & $3.192 \%$ \\
\hline $\begin{array}{l}12 \text { th } \\
\text { axis }\end{array}$ & $\begin{array}{l}\text { MAGNIFICENT KITCHEN } \\
\text { (Magnífica Cocina) } \\
\end{array}$ & $\begin{array}{l}\text { Magnificent kitchen (0.593), Craftsmanship finishes } \\
(0.585) \text {, Ecological }(0.459)\end{array}$ & $2.895 \%$ \\
\hline $\begin{array}{l}\text { 13th } \\
\text { axis }\end{array}$ & $\begin{array}{l}\text { COMMUNITY } \\
\text { ATMOSPHERE AND WITH } \\
\text { GOOD AMENITIES } \\
\text { (Ambiente de Comunidad } \\
\text { y con Servicios } \\
\text { Comunitarios) } \\
\end{array}$ & $\begin{array}{l}\text { Community atmosphere }(0.683), \text { Good amenities } \\
\begin{array}{ll}(0.545), \text { Peaceful } \quad(-0.355)\end{array}\end{array}$ & $2.885 \%$ \\
\hline $\begin{array}{l}14 \text { th } \\
\text { axis }\end{array}$ & $\begin{array}{l}\text { CLASSICAL AND } \\
\text { TRADITIONAL } \\
\text { (Clásica y Tradicional) }\end{array}$ & $\begin{array}{l}\text { Classical and traditional }(0.618) \text {, Restrained }(0.475) \text {, } \\
\text { Private atmosphere, independent }(0.448) \text {, Modern (- } \\
0.409)\end{array}$ & $2.677 \%$ \\
\hline $\begin{array}{l}15 \text { th } \\
\text { axis }\end{array}$ & $\begin{array}{l}\text { FORMAL } \\
\text { (Seriedad) }\end{array}$ & Formal (0.748) & $2.341 \%$ \\
\hline
\end{tabular}

Table 4. "Range of meaning of semantic axes and representative terms-Men (In brackets, original Spanish words)". Source: authors 
- 14th axis: with the adjectives "classical and traditional", "restrained", "private atmosphere", and the negative "modern" it represents the dimension Classical and Traditional. It explains $2.68 \%$ of the variance.

- 15th axis: this represents the dimension of Formal and only contains the adjective "formal". It explains $2.34 \%$ of the variance.

Table 4 shows the significance attributed, the original variables with their corresponding contributions and the explained variance for each factor.

\section{Women}

In the same way, for the segment of women, principal components factor analysis reduced the original 60 variables to 17 factors or independent semantic axes which explained $72.33 \%$ of the variance in the original variables. These factors are:

- 1st axis: this represents the dimension Quality and Fittings with the adjectives "urban", "quality materials and finishes", "quality", "wellequipped", "good bathrooms" and "guaranteed maintenance". With a lower correlation are the variables "good architectural design", "liveable in" and the negative "country style". It explains $7.79 \%$ of the variance.

- 2nd axis: with greater correlation, it comprises the adjectives "ecological", "craftsmanship finishes", "natural atmosphere" and "country style". With lower correlation are the variables "full of character", "original", "cosy" and the negative "impersonal". It represents the dimension Ecological, Natural and Country Style and explains $6.86 \%$ of the variance.

- 3rd axis: this represents the dimension Good Layout and comprises the adjectives "neat layout", "well laid out", "practical", "comfortable", "open plan but with well differentiated areas", "cosy", "liveable in" and "pleasant". It explains $6.84 \%$ of the variance.

- 4th axis: with the variables "luxury", "elegant", "refined" and the negative "classical and traditional" it represents the dimension Luxury and Elegant. It explains $5.63 \%$ of the sample variability.

- 5th axis: this contains the adjectives "family home", "spacious", "for growing families", "liveable in", "plenty of cupboards and auxiliary areas" 
and the negative "young". It represents the axis Spacious, Family Home and explains $4.87 \%$ of the sample variance.

- 6th axis: with the variables "outward-facing", "light", "cheerful" and the negative "inward-facing", it represents the dimension Light and Outward Facing. It explains $4.68 \%$ of the variance.

- 7th axis: it contains the adjectives "community atmosphere", "with good amenities", "fashionable", "modern" and "cheerful". It represents the dimension of Community Atmosphere and With Good Amenities and explains $3.98 \%$ of the variance.

- 8th axis: with the variables "layout with many possibilities", "flexible layout" and, with a lower correlation, "private atmosphere" and "for growing families", it represents the dimension Flexible Layout and With Many Possibilities. It explains $3.74 \%$ of the variance.

- 9th axis: this represents the dimension of Simplicity with the adjectives "simple layout", "simple" and, with a lower correlation, "impersonal". It explains $3.61 \%$ of the variance.

- 10th axis: this contains the adjectives "pleasant aspect", "light" and the negative "oppressive". It represents the dimension of Pleasant Aspect and explains $3.59 \%$ of the variance.

- 11th axis: with the variables "carefree and informal" and "young" it represents the dimension Young and Informal. It explains $3.57 \%$ of the variance.

- 12th axis: this represents the dimension Lifelong with the adjectives "timeless, doesn't go out of fashion", "for all tastes", "tailor made" and "guaranteed maintenance". It explains $3.37 \%$ of the variance.

- 13th axis: this contains the adjectives "intelligent", "safe" and with negative connotation "classical and traditional". It represents the Intelligent and Safe axis and explains $3.27 \%$ of the variance. 


\begin{tabular}{|c|c|c|c|}
\hline $\begin{array}{l}\text { Factor } \\
\text { Axes }\end{array}$ & Meaning of Factors & Representative Terms & $\begin{array}{l}\text { Contribu- } \\
\text { tion ratio }\end{array}$ \\
\hline $\begin{array}{l}\text { 1st } \\
\text { axis }\end{array}$ & $\begin{array}{l}\text { QUALITY AND FITTINGS } \\
\text { (Calidad y Equipamiento) }\end{array}$ & $\begin{array}{l}\text { Urban (0.747), Quality materials and finishes }(0.731) \text {, Quality } \\
(0.720) \text {, Well-equipped }(0.657) \text {, Good bathrooms }(0.559) \text {, } \\
\text { Guaranteed maintenance }(0.550) \text {, Good architectural design } \\
(0.453) \text {, Country style }(-0.442) \text {, Liveable in }(0.417)\end{array}$ & $7.789 \%$ \\
\hline $\begin{array}{l}\text { 2nd } \\
\text { axis }\end{array}$ & $\begin{array}{l}\text { ECOLOGICAL, NATURAL } \\
\text { AND COUNTRY STYLE } \\
\text { (Ecológica, Natural y } \\
\text { Campestre) }\end{array}$ & $\begin{array}{l}\text { Ecological }(0.740) \text {, Craftsmanship finishes }(0.675) \text {, Natural } \\
\text { atmosphere }(0.671) \text {, Country style }(0.532) \text {, Full of character } \\
(0.477) \text {, Original }(0.459) \text {, Cosy }(0.433) \text {, I mpersonal }(-0.420)\end{array}$ & $6.858 \%$ \\
\hline $\begin{array}{l}3 \text { rd } \\
\text { axis }\end{array}$ & $\begin{array}{l}\text { GOOD LAYOUT } \\
\text { (Buena Distribución) }\end{array}$ & $\begin{array}{l}\text { Neat layout }(0.792), \text { Well laid out }(0.713) \text {, Practical }(0.679) \text {, } \\
\text { Comfortable }(0.647) \text {, Open plan but with well differentiated } \\
\text { zones }(0.489), \text { Cosy }(0.479) \text {, Liveable in }(0.460) \text {, Pleasant } \\
(0.451)\end{array}$ & $6.843 \%$ \\
\hline $\begin{array}{l}\text { 4th } \\
\text { axis }\end{array}$ & $\begin{array}{l}\text { LUXURY AND ELEGANT } \\
\text { (De Lujo, Elegante) }\end{array}$ & $\begin{array}{l}\text { Luxury }(0.711) \text {, Elegant }(0.560), \text { Refined }(0.527) \text {, Classical } \\
\text { and traditional }(-0.417)\end{array}$ & $5.629 \%$ \\
\hline $\begin{array}{l}5 \text { th } \\
\text { axis }\end{array}$ & $\begin{array}{l}\text { SPACIOUS, FAMILY } \\
\text { HOME } \\
\text { (Amplia y Familiar) }\end{array}$ & $\begin{array}{l}\text { Family home }(0.798), \text { Spacious }(0.782) \text {, For growing families } \\
(0.748) \text {, Young }(-0.468) \text {, Liveable in }(0.385) \text {, Plenty of } \\
\text { cupboards and auxiliary areas }(0.367)\end{array}$ & $4.874 \%$ \\
\hline $\begin{array}{l}\text { 6th } \\
\text { axis }\end{array}$ & $\begin{array}{l}\text { LIGHT AND OUTWARD- } \\
\text { FACING } \\
\text { (Luminosa y Exterior) }\end{array}$ & $\begin{array}{l}\text { Inward-facing }(-0.829) \text {, Outward-facing, open views }(0.805) \text {, } \\
\text { Light }(0.449) \text {, Cheerful }(0.384)\end{array}$ & $4.680 \%$ \\
\hline $\begin{array}{l}\text { 7th } \\
\text { axis }\end{array}$ & \begin{tabular}{|l|} 
COMMUNITY \\
ATMOSPHERE AND WITH \\
GOOD AMENITIES \\
(Ambiente de \\
Comunidad y con \\
Servicios Comunitarios) \\
\end{tabular} & $\begin{array}{l}\text { Community atmosphere }(0.794), \text { Good amenities }(0.528) \text {, } \\
\text { Fashionable }(0.526) \text {, Modern }(0.481) \text {, Cheerful }(0.366)\end{array}$ & $3.980 \%$ \\
\hline $\begin{array}{l}\text { 8th } \\
\text { axis }\end{array}$ & $\begin{array}{l}\text { FLEXIBLE LAYOUT AND } \\
\text { WITH MANY } \\
\text { POSSIBILITIES } \\
\text { (Distribución Flexible y } \\
\text { con Muchas } \\
\text { Posibilidades) } \\
\end{array}$ & $\begin{array}{l}\text { Layout with many possibilities }(0.746) \text {, Flexible layout } \\
(0.745) \text {, Private atmosphere, independent }(0.506) \text {, For } \\
\text { growing families }(0.365)\end{array}$ & $3.736 \%$ \\
\hline $\begin{array}{l}\text { 9th } \\
\text { axis }\end{array}$ & $\begin{array}{l}\text { SIMPLICITY } \\
\text { (Sencillez) }\end{array}$ & Simple layout $(0.813)$, Simple $(0.730)$, Impersonal $(0.426)$ & $3.614 \%$ \\
\hline $\begin{array}{l}\text { 10th } \\
\text { axis }\end{array}$ & $\begin{array}{l}\text { PLEASANT ASPECT } \\
\text { (Buena Orientación) }\end{array}$ & Pleasant aspect $(0.793)$, Light $(0.576)$, Oppressive $(-0.458)$ & $3.592 \%$ \\
\hline $\begin{array}{l}11 \text { th } \\
\text { axis }\end{array}$ & $\begin{array}{l}\text { YOUNG AND INFORMAL } \\
\text { (J uvenil e Informal) }\end{array}$ & Carefree and informal (0.768), Young (0.499) & $3.572 \%$ \\
\hline $\begin{array}{l}12 \text { th } \\
\text { axis }\end{array}$ & $\begin{array}{l}\text { LIFELONG } \\
\text { (Para Toda la Vida) }\end{array}$ & $\begin{array}{l}\text { Timeless, doesn't go out of fashion }(0.686), \text { For all tastes } \\
(0.630) \text {, Tailor made }(0.413) \text {, Guaranteed maintenance } \\
(0.408)\end{array}$ & $3.373 \%$ \\
\hline $\begin{array}{l}\text { 13th } \\
\text { axis }\end{array}$ & $\begin{array}{l}\text { I NTELLIGENT AND SAFE } \\
\text { (Inteligente y Segura) }\end{array}$ & $\begin{array}{l}\text { Intelligent }(0.716) \text {, Classical and traditional }(-0.456) \text {, Safe } \\
(0.412)\end{array}$ & $3.271 \%$ \\
\hline $\begin{array}{l}\text { 14th } \\
\text { axis }\end{array}$ & $\begin{array}{l}\text { MAGNIFICENT KITCHEN } \\
\text { (Magnífica Cocina) }\end{array}$ & Magnificent kitchen (0.723), Modern (-0.367) & $2.975 \%$ \\
\hline $\begin{array}{l}15 \text { th } \\
\text { axis }\end{array}$ & $\begin{array}{l}\text { PEACEFUL ATMOSPHERE } \\
\text { (Ambiente Tranquilo) }\end{array}$ & Peaceful (0.717), Private atmosphere, independent $(0.451)$ & $2.817 \%$ \\
\hline $\begin{array}{l}16 \text { th } \\
\text { axis }\end{array}$ & $\begin{array}{l}\text { FORMAL } \\
\text { (Seriedad) } \\
\end{array}$ & Formal (0.749) & $2.373 \%$ \\
\hline $\begin{array}{l}17 \text { th } \\
\text { axis }\end{array}$ & $\begin{array}{l}\text { NOT RESTRAI NED } \\
\text { (No Sobria) }\end{array}$ & Restrained $(-0.736)$ & $2.350 \%$ \\
\hline
\end{tabular}

Table 5. "Range of meaning of semantic axes and representative terms-Women (In brackets, original Spanish words)". Source: authors 
- 14th axis: with the expressions "magnificent kitchen" and "modern" it represents the dimension of Magnificent Kitchen and explains $2.98 \%$ of the variance.

- 15th axis: this represents the Peaceful Atmosphere axis with the adjective "peaceful" and with lower correlation "private atmosphere" and explains $2.82 \%$ of the variance.

- 16th axis: this represents the dimension of Formal and only contains the adjective "formal". It explains $2.37 \%$ of the variance.

- 17th axis: with a negative correlation the adjective "restrained" which represents the axis of Not Restrained. It explains $2.35 \%$ of the variance.

Table 5 shows the significance attributed, the original variables with their corresponding contributions and the explained variance for each factor.

\subsection{Ranking semantic axes}

In addition to finding differences between the structures of the semantic axes, the axes were also analysed to see if they had a similar influence on the overall evaluation of the building. To do so, the axes were ordered according to their relation with the final evaluation using Spearman's correlation coefficients. In the case of men, this analysis identified that the axes spacious, family home, lifelong, liveable in, pleasant and practical, originality, innovative and luxury largely determined the final evaluation, with positive correlations between $0.35-0.20$ (Table 6).

The next most important were light and outward-facing, flexible layout and with many possibilities, good layout, and refined, elegant and stylish axes. The other axes do not influence on the purchase decision for a significative level of 0.05 . In the case of women, the attributes which most influenced the purchase decision (correlations between 0.35-0.20) were flexible layout and with many possibilities, lifelong, luxury and elegant, good layout, young and informal, peaceful and spacious and familiy home. Followed by simplicity, quality and fittings, not restrained, light and outward-facing and pleasant aspect (correlations between 0.20-0.10). The other axes do not influence on the purchase decision for a significative level of 0.05 . 


\begin{tabular}{|c|c|c|c|}
\hline \multicolumn{4}{|c|}{$\begin{array}{l}\text { I NFLUENCE ON THE PURCHASE DECI SI ON } \\
\text { (Spearman's correlation with the global evaluation) }\end{array}$} \\
\hline \multicolumn{2}{|l|}{ MEN } & \multicolumn{2}{|l|}{ WOMEN } \\
\hline 7. SPACIOUS, FAMILY HOME & $0.326($ s.l. 0.000$)$ & $\begin{array}{l}\text { 8. FLEXIBLE LAYOUT AND } \\
\text { WITH MANY POSSIBILITIES }\end{array}$ & 0.320 (s.l. 0.000$)$ \\
\hline 9. LIFELONG & 0.292 (s.l. 0.000$)$ & 12. LIFELONG & 0.300 (s.l. 0.001$)$ \\
\hline $\begin{array}{l}\text { 2. LIVEABLE IN, PLEASANT AND } \\
\text { PRACTICAL }\end{array}$ & 0.255 (s.l. 0.000$)$ & 4. LUXURY AND ELEGANT & 0.280 (s.l. 0.002$)$ \\
\hline $\begin{array}{l}\text { 1. ORIGINALITY, INNOVATIVE } \\
\text { AND LUXURY }\end{array}$ & 0.222 (s.l. 0.000) & 3. GOOD LAYOUT & 0.217 (s.l. 0.016) \\
\hline $\begin{array}{l}\text { 6. LIGHT AND OUTWARD- } \\
\text { FACING }\end{array}$ & 0.174 (s.l. 0.002 ) & 11. YOUNG AND INFORMAL & 0.215 (s.l. 0.018$)$ \\
\hline $\begin{array}{l}\text { 11. FLEXIBLE LAYOUT AND } \\
\text { WITH MANY POSSIBILITIES }\end{array}$ & 0.162 (s.l. 0.004$)$ & 15. PEACEFUL ATMOSPHERE & 0.206 (s.l. 0.023$)$ \\
\hline 3. GOOD LAYOUT & 0.151 (s.l. 0.006) & 5. SPACIOUS, FAMILY HOME & 0.202 (s.l. 0.026) \\
\hline $\begin{array}{l}\text { 4. REFINED, ELEGANT AND } \\
\text { STYLISH }\end{array}$ & 0.135 (s.l. 0.015) & 9. SIMPLICITY & -0.173 (s.l. 0.056) \\
\hline 12. MAGNIFICENT KITCHEN & 0.089 (s.l. 0.110) & 1. QUALITY AND FITTINGS & 0.127 (s.l. 0.165) \\
\hline $\begin{array}{l}\text { 8. COUNTRY STYLE AND } \\
\text { NATURAL CHARACTER }\end{array}$ & 0.088 (s.l. 0.112 ) & 17. NOT RESTRAINED & 0.127 (s.l. 0.163$)$ \\
\hline $\begin{array}{lll}\text { 5. QUALITY, FITTINGS } & \text { AND } \\
\text { SECURITY } & & \\
\end{array}$ & 0.080 (s.l. 0.153$)$ & $\begin{array}{l}\text { 6. LIGHT AND OUTWARD- } \\
\text { FACING }\end{array}$ & 0.115 (s.l. 0.207$)$ \\
\hline $\begin{array}{l}\text { 13. COMMUNITY ATMOSPHERE } \\
\text { AND WITH GOOD COMMUNAL } \\
\text { SERVICES }\end{array}$ & 0.049 (s.l. 0.377$)$ & 10. PLEASANT ASPECT & 0.101 (s.l. 0.268) \\
\hline 15. FORMAL & -0.040 (s.l. 0.473$)$ & $\begin{array}{l}\text { 2. ECOLOGICAL, NATURAL } \\
\text { AND COUNTRY STYLE }\end{array}$ & 0.099 (s.l. 0.279) \\
\hline 14. CLASSICAL AND TRADITIONAL & 0.026 (s.l. 0.636) & $\begin{array}{l}\text { 7. COMMUNITY ATMOSPHERE } \\
\text { AND WITH GOOD COMMUNAL } \\
\text { SERVICES }\end{array}$ & 0.070 (s.l. 0.445) \\
\hline 10. YOUNG AND INFORMAL & -0.005 (s.l. 0.923) & 16. FORMAL & -0.042 (s.l. 0.648$)$ \\
\hline & & 13. INTELLI GENT AND SAFE & 0.018 (s.l. 0.844$)$ \\
\hline & & 14. MAGNIFICENT KITCHEN & -0.010 (s.l. 0.913) \\
\hline
\end{tabular}

Table 6. "Range Factor ordering according to influence on the purchase decision". Source:

$$
\text { authors }
$$

\subsection{Comparative analysis: semantic profiles}

Figure 2 shows the stimulus of a particular flat which was not included in the previous factor analysis. Figure 3 shows the comparative semantic profiles. The first bar represents the overall assessment. All values are standardized: centered with respect to the sample average and measured in standard deviation units.

It can be seen that although the evaluations of the different attributes are not very different, the global evaluation is indeed very different: while women would buy the flat, men would not. In most of the attributes both genders coincide, thus men and women consider that it is a quality building, outward facing and light, with a flexible layout and possibilities, young, formal, with no community atmosphere, no country style finish or luxury aspect. However, they differ in other evaluations: while women consider that the flat is well-laid out, for life, spacious and with a family character, men consider the opposite. Furthermore, men evaluate the kitchen positively whereas women do so negatively. 

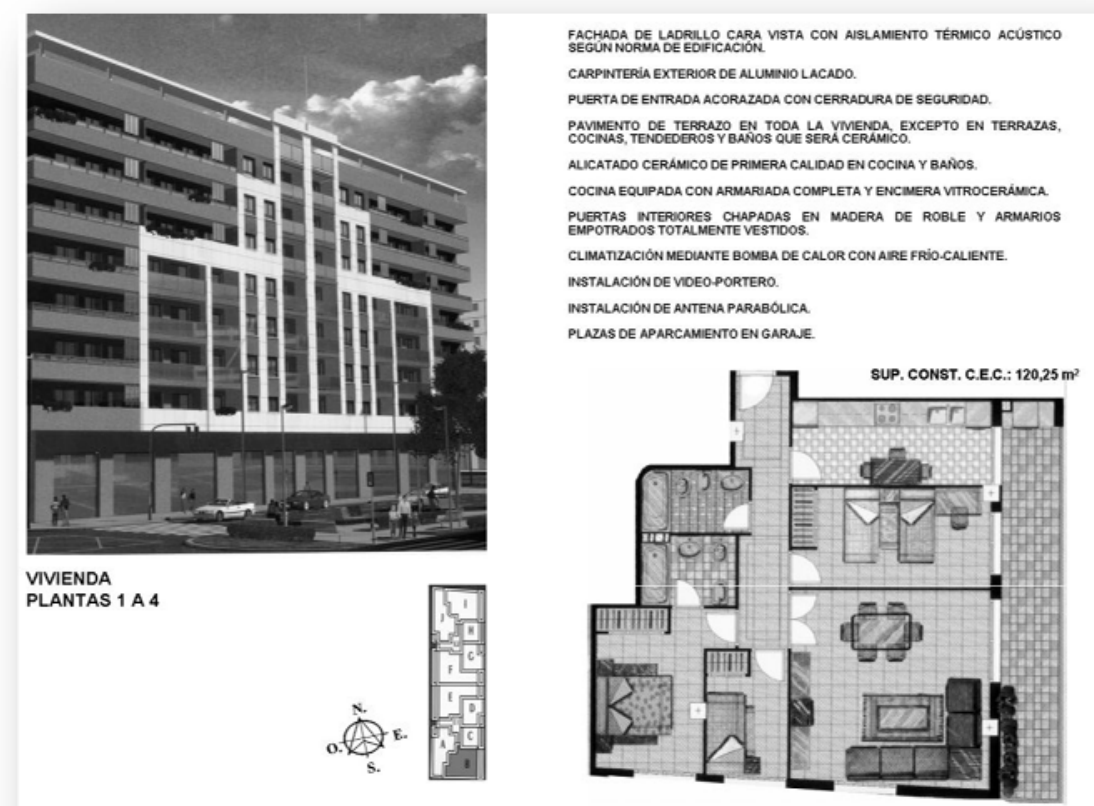

VIVIENDA

VIVIENDA
PLANTAS 1 A 4

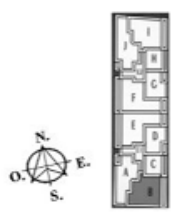

Figure 2. "Stimulus of a particular flat". Source: authors
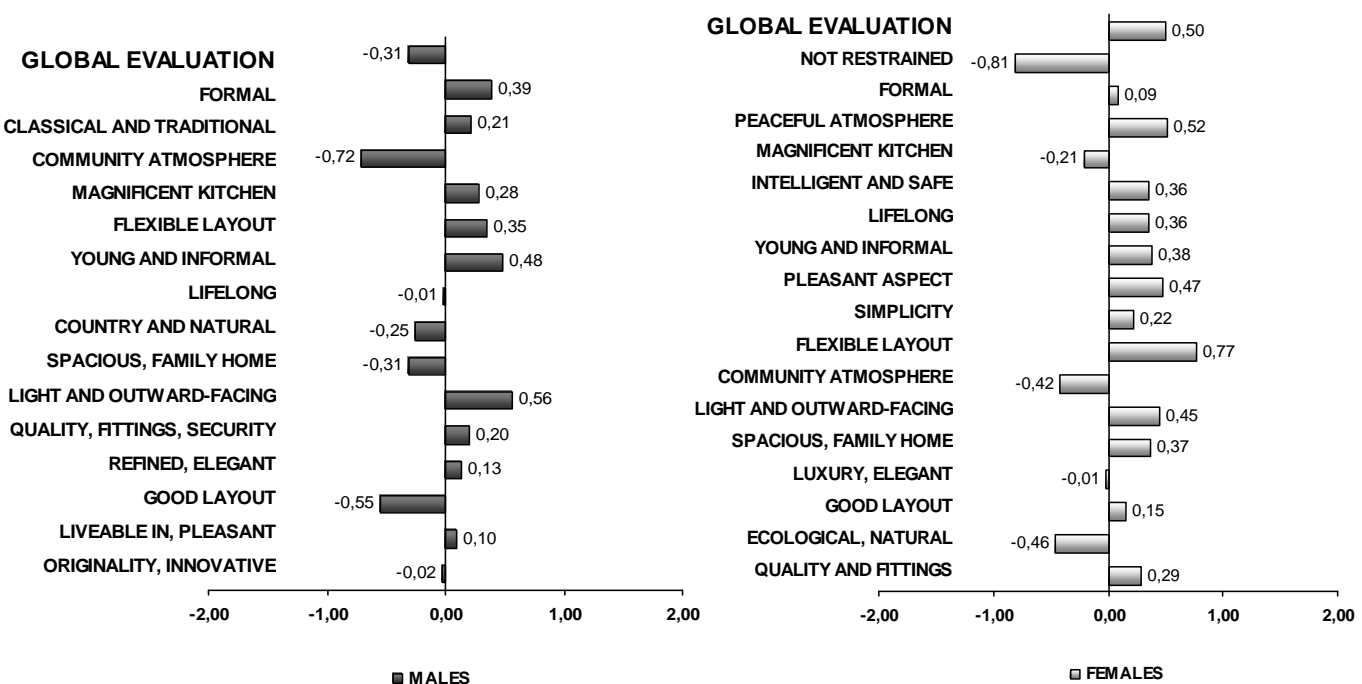

Figure 3. "Comparison of semantic profiles (Men-Women)". Source: authors

The different global evaluation of the flat by both genders can be explained by analysing the attributes which influence the purchase decision. Thus, it can be seen that women evaluate positively the attributes which most influence their purchase decision. They perceive the flat as having the following attributes: a flexible layout, being for life and well-laid out, which makes their global evaluation positive. In 
contrast, men evaluate negatively the attributes most relevant to their purchase decision: spacious, family character and that it is perceived as a home for life. These evaluations may justify the fact that, in the end, the men evaluated the building negatively.

\section{Discussion}

This paper identifies the structure of concepts used by men and women to describe their perception of properties on sale using differential semantics.

This study has several implications. From a theoretical point of view it can be concluded that the two collectives use different conceptual schemes to evaluate a real estate promotion. Thus, the discriminant analysis and factor analysis results show differences between men and women's perceptions. In this regard, several studies report significant differences between the two groups' assessment of building design (Nasar, 1989, 1997; Imamoglu, 2000; Akalin et. al., 2009).

At application level, several results are worth emphasizing.

Firstly, the perception of a property on sale may be expressed through a set of independent concepts known as semantic axes, specifically, 15 axes for males (explained $64.02 \%$ of the variance) and 17 axes for females (explained $72.33 \%$ of the variance). In general, there is a set of axes which coincide in both genders, some related to building design (luxury), layout (good layout, flexible layout), fittings (quality and fittings, magnificent kitchen, good amenities), spaciousness (spacious and family home), aspect (light and outward facing) and appearance (country style and natural character, lifelong, young and informal, formal).

However, although the names of many axes coincide, some nuances appear in terms of the meaning attributed to them (Table 7). Thus for example, in terms of building design, men differentiate a building in a refined style (stylish, elegant and with good architectural design) from an original building (innovative, designer and luxury). For women however, these concepts are related.

Another example can be found in the layout attributes. For both genders, a good layout means a neat, rational layout which is open plan but with well differentiated areas. However, women also associate good layout with the concepts of a practical, comfortable and cosy flat. For men on the other hand, a practical, comfortable flat 
is not related to layout, but rather to a flat which does not feel oppressive, has plenty of cupboard space and good bathrooms. For both genders a flexible distribution is one which offers possibilities. But in addition, women associate this characteristic with the concepts of privacy and growing families.

\section{LIST OF FACTORS MEN-WOMEN}

\section{FACTOR ANALYSIS MEN}

\begin{tabular}{|c|c|}
\hline \multirow{2}{*}{ 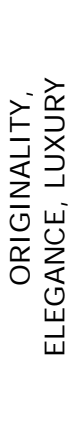 } & $\begin{array}{l}\text { 1st axis: ORIGINALITY, INNOVATIVE AND } \\
\text { LUXURY } \\
\text { Original }(0.792), \text { I nnovative }(0.750), \\
\text { Designer }(0.743) \text {, Full of character }(0.735) \text {, } \\
\text { Luxury }(0.521) \text {, Fashionable }(0.466) \text {, } \\
\text { Delightful }(0.450) \text {, Simple }(-0.403)\end{array}$ \\
\hline & $\begin{array}{l}\text { 4th axis: REFINED, ELEGANT AND } \\
\text { STYLISH } \\
\text { Refined (0.640), Stylish (0.534), Elegant } \\
\text { (0.516), Good architectural design }(0.495) \text {, } \\
\text { Impersonal }(-0.423) \text {, Good bathrooms } \\
(0.411)\end{array}$ \\
\hline
\end{tabular}

\begin{tabular}{|c|c|}
\hline 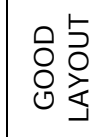 & $\begin{array}{l}\text { 3rd axis: GOOD LAYOUT } \\
\text { Neat layout }(0.832) \text {, Well laid out }(0.687) \text {, } \\
\text { Simple layout }(0.686) \text {, Open plan but with } \\
\text { well differentiated areas }(0.679)\end{array}$ \\
\hline
\end{tabular}

\begin{tabular}{|c|c|}
\hline 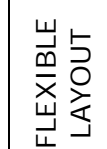 & $\begin{array}{l}\text { 11th axis: FLEXIBLE LAYOUT AND WITH } \\
\text { MANY POSSIBILITIES } \\
\text { Layout with many possibilities }(0.783) \text {, } \\
\text { Flexible layout }(0.767)\end{array}$ \\
\hline
\end{tabular}

\begin{tabular}{|c|c|}
\hline 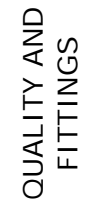 & $\begin{array}{l}\text { 5th axis: QUALITY, FITTINGS AND } \\
\text { SECURITY } \\
\text { Safe }(0.711) \text {, Guaranteed maintenance } \\
(0.699) \text {, Quality materials and finishes } \\
(0.681) \text {, Quality }(0.609) \text {, Well-equipped } \\
(0.436)\end{array}$ \\
\hline
\end{tabular}

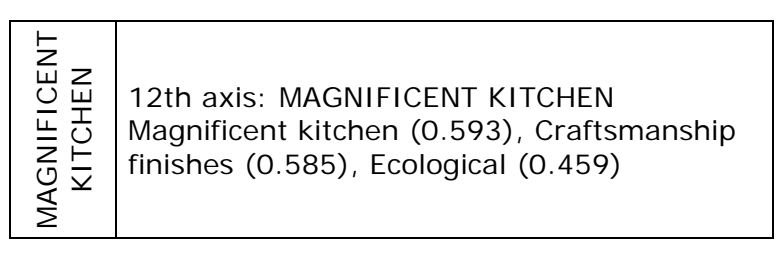

\begin{tabular}{|c|c|}
\hline 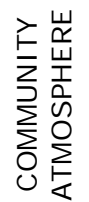 & $\begin{array}{l}\text { 13th axis: COMMUNITY ATMOSPHERE AND } \\
\text { GOOD COMMUNAL SERVICES } \\
\text { Community atmosphere }(0.683) \text {, Good } \\
\text { amenities }(0.545) \text {, Peaceful }(-0.355)\end{array}$ \\
\hline
\end{tabular}

\section{FACTOR ANALYSIS WOMEN}

4th axis: LUXURY AND ELEGANT

Luxury (0.711), Elegant (0.560), Refined

(0.527), Classical and traditional (-0.417)

3rd axis: GOOD LAYOUT

Neat layout (0.792), Well laid out (0.713),

Practical (0.679), Comfortable (0.647), Open

layout but with well differentiated zones $(0.489)$,

Cosy (0.479), Liveable in (0.460), Pleasant (0.451)

8th axis: FLEXIBLE LAYOUT AND WITH MANY POSSIBILITIES

Layout with many possibilities (0.746), Flexible layout (0.745), Private atmosphere,

independent $(0.506)$, For growing families (0.365)

1st axis: QUALITY AND FITTINGS

Urban (0.747), Quality materials and finishes

(0.731), Quality (0.720), Well-equipped (0.657),

Good bathrooms (0.559), Guaranteed

maintenance (0.550), Good architectural design

$(0.453)$, Country style $(-0.442)$, Liveable in

(0.417)

14th axis: MAGNIFICENT KITCHEN

Magnificent kitchen (0.723), Modern (-0.367)

7th axis: COMMUNITY ATMOSPHERE AND GOOD COMMUNAL SERVICES

Community atmosphere (0.794), Good amenities (0.528), Fashionable (0.526), Modern (0.481), Cheerful (0.366) 

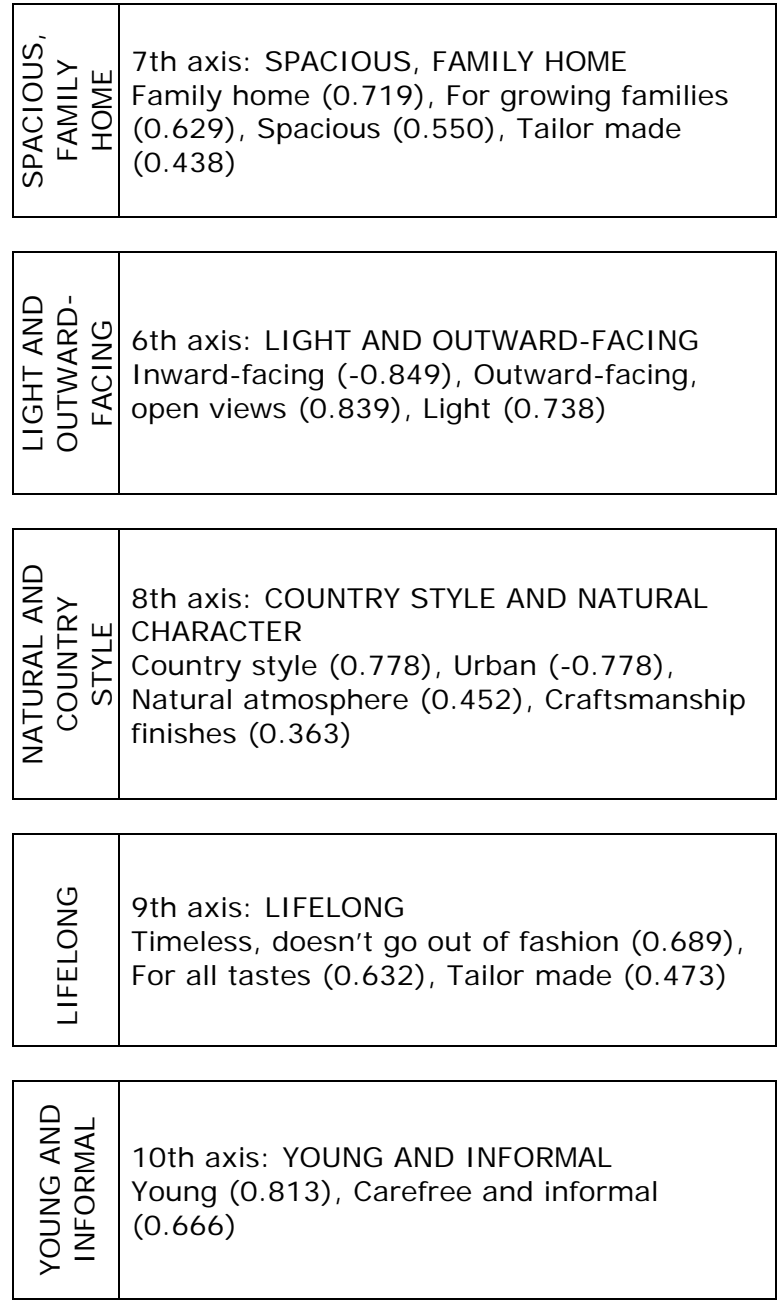

\begin{tabular}{|c|c|}
\hline 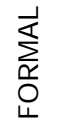 & $\begin{array}{l}\text { 15th axis: FORMAL } \\
\text { Formal }(0.748)\end{array}$ \\
\hline
\end{tabular}

5th axis: SPACIOUS, FAMILY HOME

Family home $(0.798)$, Spacious $(0.782)$, For growing families $(0.748)$, Young $(-0.468)$, Liveable in (0.385), Plenty of cupboards and auxiliary areas $(0.367)$

\section{6th axis: LIGHT AND OUTWARD-FACING \\ Inward-facing (-0.829), Outward-facing, open \\ views (0.805), Light (0.449), Cheerful (0.384)}

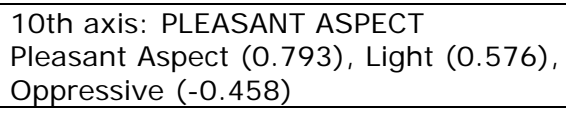

2nd axis: ECOLOGICAL, NATURAL AND COUNTRY STYLE

Ecological (0.740), Craftsmanship finishes

(0.675), Natural atmosphere (0.671), Country style $(0.532)$, Full of character $(0.477)$, Original $(0.459)$,$) , Cosy (0.433)$, Impersonal $(-0.420)$

\section{2th axis: LIFELONG}

Timeless, doesn't go out of fashion (0.686), For all tastes $(0.630)$, Tailor made $(0.413)$,

Guaranteed maintenance $(0.408)$

11th axis: YOUNG AND INFORMAL

Carefree and informal (0.768), Young (0.499)

16th axis: FORMAL

Formal (0.749)

Table 7. "Comparative factors Men-Women". Source: authors

In terms of the characteristics related to quality and fittings in a building, there are also different shades of meaning. Thus, while men associate quality with safety, women associate it with an urban character and with a building with good bathrooms and a good architectural design. Furthermore, the concept of magnificent kitchen, which for males implies ecological buildings and handcrafted finishes, for women is associated negatively with the concept of a modern building. There are also differences in the axis of community atmosphere and amenities. Men associate it with a lack of tranquility and women with fashionable, modern and cheerful buildings. 
The concepts of a spacious and family flat are also found in both analyses. Thus, a spacious building for both genders is a family-type property suitable for growing families. However, men consider spacious buildings to be those which are tailor made, whereas for women they are properties with good cupboard space, liveable in and not young in style.

Another aspect on which both genders appear to agree is light and the concept of an outward facing building as opposed to an inward facing one. The only discrepancy in the meanings is that women also include a pleasant aspect component, so that buildings with a pleasant aspect are light and not oppressive.

The characteristics related to the flat's appearance or character also reflect similarities and differences. Thus, for both genders, a natural, country-style dwelling has handcrafted finishes. However, females attach more meanings to this attribute as they consider that a country-style property is ecological, original, characterful and also cosy. The perception of a timeless or lifelong property coincides, both genders associating it with all types of property and those which are tailor-made. The perceptions of a young, informal and formal building also coincide.

The remaining axes are concepts which only form part of either men's or women's mental patterns. Thus for example, the perception of an intelligent building, which for many females is related to the concepts of a safe, non-classical building, has no meaning at all for males. In contrast, males attach their own meaning to concepts of a habitable, comfortable and practical building, associating them with the concepts of a building which does not feel oppressive, is tranquil and has good cupboard space and bathrooms.

Attention must be paid not only to the meanings attributed by both genders, but also to the different ordering obtained after factor analysis. This ordering was done on the basis of the explained variance per factor in order to establish the characteristics which have been seen as different between flats by both groups. The results demonstrate that men differentiate some buildings from others basically on their perception of originality, innovation and luxury, the aspect of a habitable, comfortable and practical home and good layout. Women however, although they also notice good layout, differentiate properties mainly in terms of quality and fittings and their natural and ecological character. 
Secondly, the importance of these axes in the purchase decision also differs for both genders (Table 6). Thus, the most influential attribute for men is whether the property is perceived as being spacious and having a family character, while for women it should have a flexible layout and offer possibilities. However, for both collectives the perception of lifelong, design and luxury is also relevant. In addition to these attributes, for men it is important that the building is perceived as habitable, comfortable and practical, while for women a good layout and young character is relevant. This final attribute (young, informal character) should be emphasised since while for women it is relevant, for men do not influence on the purchase decision. In terms of the remaining factors, it can be seen that for both genders an outward facing aspect and light are important whereas the kitchen, formal appearance, natural or country-style and amenities are not important.

Thirdly, semantic profiles for both collectives have been obtained with regard to a specific flat on sale. The differences in perception may help to interpret men and women's different evaluations of a specific flat. Thus differences in the evaluation of apparently similar attributes (good layout, spacious and family and good kitchen) are different, possibly because they correspond to different concepts. Furthermore, the different influence of each attribute on the global evaluation explains the global evaluation.

\section{Conclusions}

In short, using the semantic differential technique it is possible to identify differences in the way both genders express their perception of a property on sale and the influence this has on the purchase decision. In terms of application, the symbolic evaluation of products is complementary information which can help property developers and architects to develop new promotions which attempt to satisfy consumers' specific expectations. Thus the company can focus its sales strategies on the target market by covering its needs, interests and preferences, something which is becoming increasingly necessary in competitive markets.

With regard to the limitations, it is important to highlight the fact that although this study has general validity, since the proposed methodology can be applied to other products (online renting, sales of second homes, etc.), the results obtained cannot be generalised as they are specific to the segment of population and geographical area in the study. This is due not only to language differences; the culture, 
background and experiences of the consumer are influential in determining their response to products (Dittmar, 1992). Thus, this study is focused on a specific segment of population, assumed as representative of a given market segment. This limitation is imposed by the need to work with homogenous population groups, the inclusion of different groups could alter the structure of the semantic axes.

In terms of future lines of work, now that the affective dimensions of both genders have been obtained it would be interesting to determine what building design elements cause them. This relationship between design elements and semantic attributes could be determined applying statistical treatments such as linear regression, neural networks or fuzzy logic.

\section{References}

Akalin, A., Yildirim, K., Wilson, C., \& Kilicoglu, O. (2009). Architecture and engineering students' evaluations of house façades: preference, complexity and impressiveness. J ournal of Environmental Psychology, 29 (1), 124-132.

Basilevsky, A. (1994). Statistical factor analysis and related methods: Theory and application. New York: Wiley.

Berlyne, D.E. (1971). Aesthetics and psychobiology. New York: Appleton-CenturyCrofts.

Devlin, K. (1990). An examination of architectural interpretation: architects versus nonarchitects. J ournal of Architecture and Planning Research, 7(3), 235-244.

Devlin, K., \& Nasar, J. (1989). The beauty and the beast: Some preliminary comparisons of "high" versus "popular" residential architecture and public versus architect judgments of same. Journal of Environmental Psychology, 9, 333-344.

Dittmar, H. (1992). The social psychology of material possessions: To have is to be. New York: St. Martin's Press.

Duffy, M., Bailey, S., Beck, B., \& Barker, D.G. (1986). Preferences in nursing home design: A comparison of residents, administrators and designers. Environment and Behavior, 18, 246-257.

Evans, G. (1980). Environmental cognition. Psychology Bulletin, 88, 259-287. 
Flury, B. (1988). Common principal components and related multivariate models. New York: Wiley.

Friedman, C., Balling, J.D., \& Valadez, J.J. (1985). Visual preference for office buildings: A comparison of architects and non-architects. Paper Presented at the Annual Conference of the Environmental Design Research Association, New York.

Gans, H. (1978). Towards a human architecture: A sociologist's view of the profession. Journal of Architectural Education, 31(2), 26-31.

Gifford, R. (1980). Judgements of the built environment as a function of individual differences and context. Journal of Man-Environment Relations, 1, 22-31.

Gifford, R., Hine. D.W., Muller-Clemm, W., Reynolds, D., \& Shaw, K. (2000). Decoding modern architecture. A lens model approach for understanding the aesthetic differences of architects and laypersons. Environment and Behavior, 32(2), 163-187.

Groat, L. (1982). Meaning in post-modern architecture: An examination using the multiple sorting task. J ournal of Environmental Psychology, 2, 3-22.

Jindo, T., Hirasago, K., \& Nagamachi, M. (1995). Development of a design support system for office chairs using 3-D graphics. International Journal of Industrial Ergonomics, 15(1), 49-62.

Lewicki, P., Hill, T., \& Bizot, E. (1988). Acquisition of procedural knowledge about a pattern of stimuli that cannot be articulated. Cognitive Psychology, 20, 24-37.

Michelson, W. (1976). Man and his urban environment. Massachusetts: AddisonWesley.

Moore, G.T. (1979). Knowing about environmental knowing: The state of theory and research on environmental cognition. Environment and Behavior, 11, 33-70.

Nasar, J.L. (1989). Symbolic meanings of house styles. Environment and Behavior, 21(3), 235-257.

Nasar, J.L., \& Purcell, T. (1990). Beauty and the beast extended: Knowledge structure and evaluations of houses by Australian architects and non-architects. 
In H. Pamir, V. Imamoglu and N. Teymur (Eds.), Culture-Space-History. Proceedings 11th International Conference of the International Association for People-Environment Studies, Ankara, Turkey.

Nasar, J.L., Valencia, H., Omar, Z.A., Chueh, S.C., \& Hwang, J.H. (1985). Out of sight further from mind. Destination visibility and distance perception. Environment and Behavior, 17, 627-639.

Osgood, C.E., \& Suci, G.J. (1955). Factor analysis of meaning. Journal of Experimental Psychology, 50, 325-338.

Osgood, C.E., Suci, G.J., \& Tannenbaum, P.H. (1957). The measurement of meaning. Urbana: University of Illinois Press.

Purcell, A.T. (1986). Environmental perception and affect: A schema discrepancy model. Environment and Behavior, 18, 3-30.

Purcell, A.T. (1987). The relationship between buildings and behavior. Building and Environment, 22, 215-232.

Purcell, A.T., \& Nasar, J.L. (1992). Experiencing other people's houses: A model of similarity and differences in environmental experience. Journal of Environmental Psychology, 12, 199-211.

Royse, D.C. (1969). Social inferences via environmental cues. Doctoral dissertation, Massachusetts Institute of Technology, Cambridge.

Stamps, A.E. (1991a). Comparing preferences of neighbors and neighborhood design review board. Environment and Behavior, 23(5), 616-629.

Stamps, A.E. (1991b). Public preferences for high rise buildings: Stylistic and demographic effects. Perceptual and Motor Skills, 72, 839-844.

Stamps, A.E., \& Nasar, J.L. (1997). Design review and public preferences: Effects of geographical location, public consensus, sensation seeking, and architectural styles. J ournal of Environmental Psychology, 17, 11-32.

Wethman, C. (1968). The social meaning of the physical environment. Doctoral dissertation, University of Southern California, Los Angeles. 
Zuckerman, M. (1994). Behavioral expressions and biosocial bases of sensation seeking. New York: Cambridge University Press.

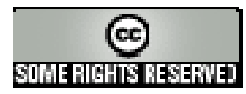

Article's contents are provided on a Attribution-Non Commercial 3.0 Creative commons license. Readers are allowed to copy, distribute and communicate article's contents, provided the author's and Journal of Industrial Engineering and Management's names are included. It must not be used for commercial purposes. To see the complete license contents, please visit http://creativecommons.org/licenses/by-nc/3.0/. 